\title{
From the Depths: Rich Pickings of Principles of Sustainable Development and General International Law on the Ocean Floor-the Seabed Disputes Chamber's 2011 Advisory Opinion
}

\author{
Duncan French* \\ Professor of International Law, School of Law, University of Sheffield, Sheffield S3 7ND, \\ United Kingdom \\ E-mail: d.french@sheffield.ac.uk
}

\begin{abstract}
In February 2011, the Seabed Disputes Chamber of the International Tribunal for the Law of the Sea handed down its Advisory Opinion in Responsibilities and Obligations of States Sponsoring Persons and Entities with respect to Activities in the Area. Although primarily focused on governance of the deep seabed beyond national jurisdiction ('the Area'), the Opinion has wider relevance for both international environmental law and general international law. More specifically, although sustainable development is not directly referenced in the Opinion, this article argues that it goes a long way towards strengthening many of the emerging normative rules associated with it. Using the International Law Association's 2002 New Delhi Declaration of Principles of International Law relating to Sustainable Development as a framework, this article specifically analyses the Advisory Opinion's contribution to the sustainable use of natural resources, the precautionary approach, common but differentiated responsibilities, and the principle of good governance.
\end{abstract}

\section{Keywords}

Advisory Opinion, deep seabed, the Area, common heritage of mankind, sponsoring States, sustainable development, environmental impact assessment, precautionary approach, common but differentiated responsibilities, state responsibility, marine mining, good governance, due diligence, actio popularis

\section{Introduction}

On 1 February 2011, the Seabed Disputes Chamber of the International Tribunal for the Law of the Sea (ITLOS) handed down its Advisory Opinion in

* Also co-rapporteur of the International Law Association Committee on International Law on Sustainable Development. Many thanks to the participants in the workshop on "Sustainable Development Principles in the Decisions of International Courts and Tribunals" held at the International Development Law Organization (IDLO), Rome (June 2011), where an original version of this article was presented. With thanks to the anonymous reviewers for their comments. 
Responsibilities and Obligations of States Sponsoring Persons and Entities with respect to Activities in the Area. ${ }^{1}$ This Opinion is noteworthy in several respects. It was the first judicial act of the Chamber, the Opinion was adopted by unanimity, and it highlights the increased trend towards significant exploration of the deep seabed, which in time will undoubtedly transform into exploitation of its natural resources. But arguably more significant than any of this, is the content of the Advisory Opinion itself, which sets out, in a coherent, forwardlooking manner, the responsibilities of States when they sponsor activities in the deep seabed beyond national jurisdiction, otherwise known as the Area. The purpose of this article is not to provide a detailed analysis of the Advisory Opinion, in particular as it relates to the detailed regulation and potential liability of sponsoring States. ${ }^{2}$ These issues are hugely important for the operational effectiveness of the Area and certain key aspects will be covered in this article as and when they arise.

Rather, the focus of this article is notably different: it is to consider how far and to what extent the Seabed Disputes Chamber, in its Advisory Opinion, addresses foundational issues of international environmental law and the international law on sustainable development. Although sustainable development is not directly referenced in the Advisory Opinion, it is far from hyperbolic to suggest that in this Advisory Opinion we see discussion of each of the seven principles identified by the International Law Association (ILA) in its 2002 New Delhi Declaration of Principles of International Law relating to Sustainable Development, including the sustainable use of natural resources, the precautionary approach, common but differentiated responsibilities, and the principle of good governance. Are they all discussed coherently and comprehensively? No, that would be difficult to expect and indeed probably beyond the judicial role within the confines of one Advisory Opinion. But does the Advisory Opinion give fresh insights into, and prompt new thinking on, many of these principles? Undoubtedly so. To that extent, the contribution of the 2011 Advisory Opinion to international environmental law and general international law is not only to be welcomed, but also to be studied closely. Simply because its subject-matter deals with arguably one of the least understood, and so far least operational, international regimes for the utilization of some of the remotest and least accessible natural resources should not

${ }^{1} \mathrm{http} / /$ www.itlos.org/fileadmin/itlos/documents/cases/case_no_17/adv_op_010211.pdf (last accessed: July 2011). Hereinafter: Advisory Opinion.

2 See D. Freestone, 'Advisory Opinion of the Seabed Disputes Chamber' (9 March 2011) 15(7) ASIL Insights; and D. Anton, R. Makgill and C. Payne, 'Seabed Mining-Advisory Opinion on Responsibility and Liability' (2011) 41 Environmental Policy and Law 60-65. 
diminish its general significance. In short, whilst its focus and ultimate relevance are on the deep seabed, the 2011 Advisory Opinion will equally make a substantive contribution to our understanding of issues that are of global relevance.

\section{Background to the Advisory Opinion}

The deep seabed has been the subject of active international discussion since Dr. Arvid Pardo, the Maltese Ambassador to the United Nations, in 1967 proposed collective oversight of its natural resources as a matter of common interest to mankind. ${ }^{3}$ This discussion translated into international activity with the adoption in the United Nations General Assembly of the 1969 'Moratorium' Resolution ${ }^{4}$ and the 1970 Declaration of Principles Governing the Sea-Bed and the Ocean Floor, and the Subsoil Thereof, Beyond the Limits of National Jurisdiction. ${ }^{5}$ Although the extent of the resources has quite understandably never been precisely determined, their potential significance is clear. As the International Seabed Authority notes:

The existence on the deep ocean floor of potentially valuable polymetallic nodules has been known for more than a century. Scientists investigating these rocks, also known as manganese nodules, found that they contained valuable metals such as nickel, manganese, copper and cobalt. About the shape and size of potatoes, the dark-coloured nodules lie strewn atop the seabed, notably in the central Pacific and Indian oceans... More recently, in the late 1970s, researchers learned of other mineral resources in the deep oceans, containing many of the same metals, along with gold and silver. These are polymetallic sulphides, formed around hot springs in active volcanic areas, and cobalt-rich crusts, fused to the underlying rock around ridges and seamounts in all the world's oceans. ${ }^{6}$

${ }^{3}$ For a general discussion of the Area, see S. Nandan, 'Administering the Mineral Resources of the Deep Seabed' in: D. Freestone, R. Barnes and D. Ong (eds.), The Law of the Sea: Progress and Prospects (Oxford, Oxford University Press, 2006) 75-92.

${ }^{4}$ UNGA Res. 2574 D (XXIV) (1969).

5 UNGA Res. 2749 (XXV) (1970).

${ }^{6}$ International Seabed Authority (hereinafter, the Authority), Brochure; http://www.isa.org .jm/files/documents/EN/Brochures/ENG1.pdf (last accessed: July 2011). For clarification, the LOSC defines 'resources' in the context of the Area as: "all solid, liquid or gaseous mineral resources in situ in the Area at or beneath the sea-bed, including polymetallic nodules" (LOSC 133(a)), with Article 133(b) going on to note that "resources, when recovered from the Area, are referred to as 'minerals". 
As uncertain as the extent of the natural resources was, the legal and political debates nevertheless quickly revealed a significant schism in approach. Although the notion of "common heritage of mankind" was settled upon as the conceptual framework under which the Area would be governed, the detail of its governance and importantly its customary status increasingly became matters of high politics. While some of this reflected what would become broader divisions between developed and developing countries surrounding the New International Economic Order later in the 1970 s, ${ }^{7}$ a particular issue as regards the Area was the extent to which a State's traditional freedom of the high seas could be curtailed by a General Assembly Resolution, prior to the entry into force (or at least the adoption and signature) of a treaty-based regime. Whereas many, primarily developing, States felt the combined effect of the two General Assembly Resolutions was to restrict unilateral action, many developed States were equally adamant that they were political aspirations and that until such a treaty system was concluded, States remained free to exercise their traditional rights and freedoms. ${ }^{8}$

Such a regime came into being with Part XI of the 1982 United Nations Convention on the Law of the Sea (LOSC or the Convention; 21 International Legal Materials 1261 (1982); in force 16 November 1994). Equally well-rehearsed was the almost immediate dislike by numerous developed States of the bureaucracy of the institutions established and the alleged deviation from fundamental precepts of a market economy. The most vocal (and most interested) of these States thereby established the Reciprocal States Regime, which, if not a competing system in a technical sense, certainly undermined the (hoped for) universal nature of the International Seabed Authority, which was to be established by the Convention on its entry into force. The 1994 Implementation Agreement ${ }^{9}$ significantly altered the operation of the regime-with the hope and expectation that many of the developed States that had yet to ratify the LOSC would now do so-and whilst the overarching ethos remained institutional management of the Area's natural resources and universal benefit arising from exploitation thereof (both reflected in the ideal of the common heritage of mankind), the regime as it now exists is quite distinct from that originally envisaged, with much more emphasis on market

\footnotetext{
7 See R. Prakesh Anand, Legal Regime of the Sea-bed and the Developing Countries (New Delhi, Thomson Press, 1976).

8 Cf. D. Rothwell and T. Stephens, The International Law of the Sea (Oxford, Hart, 2010) 128: "The major powers certainly took the view that the [1969] resolution was recommendatory only, while at the same time, and somewhat paradoxically, taking steps to restrain deep seabed mining".

9 Agreement on the Implementation of Part XI of the 1982 Law of the Sea Convention (33 ILM 1309 (1994)).
} 
economics and much less emphasis on the founding (re)distributive function. Certain aspects of the current regime will be discussed in due course.

\section{The Particular Needs of Sponsoring (Developing) States}

The Advisory Opinion discussed in this article arose from a request by Nauru for legal clarification as to the scope of its and other developing countries' responsibilities when they sponsor natural or legal persons to undertake exploration activities in the Area. Although there is nothing to stop a country itself from undertaking such activities, in reality and especially for developing countries this is most likely to occur by private entities or, in some instances, Stateowned companies. Nauru's request arose from an application for approval of a plan of work for exploration submitted by Nauru Ocean Resources Inc., submitted at the same time as an application by Tonga Offshore Mining Ltd. (sponsored by Tonga), both in $2008 .{ }^{10}$ Nauru was concerned that as a developing country it could face prohibitive potential liabilities by sponsoring a private entity. Nauru, like many other developing States, does not yet possess the technical and financial capacity to undertake seafloor mining in international waters. To participate effectively in activities in the Area, these States must engage entities in the global private sector (in much the same way as some countries seek to attract foreign direct investment). Not only do some developing States lack the financial capacity to execute a seafloor mining project in international waters, but some also cannot afford exposure to the legal risks potentially associated with such a project. ${ }^{11}$

The requirement of sponsorship (as a separate and additional requirement to the obligation that such entities either be nationals of the State party or be effectively controlled by nationals of that State party, or indeed the State itself $)^{12}$ ensures a direct link between the entity seeking to undertake activities

\footnotetext{
${ }^{10}$ Further details can be found at Advisory Opinion, paragraph 4. Consideration by the Authority of the applications was postponed at the request of the applicants in 2009. However, on 19 July 2011, during the seventeenth session of the Authority, and following the delivery of the Advisory Opinion, the Seabed Council approved the applications. During the debate on the applications, Germany made note of "the recent advisory opinion of the Seabed Disputes Chamber in which the judges said that sponsoring States should have laws, regulations and administrative measures in place for 'active supervision of the activities of the sponsored contractor"'(Press Release (19 July 2011): Seabed Council approves Applications for Exploratory Contracts with Authority in Deep Seabed Area; http://www.isa.org.jm/files/ documents/EN/Press/Press11/SB-17-11.pdf (last accessed: July 2011)).

${ }_{11}$ ISBA/16/C/6, paragraph 5 quoted by the Chamber in Advisory Opinion, paragraph 4.

12 Both requirements are contained in LOSC Article 153(2)(b) and Annex III, Article 4.
} 
in the Area ${ }^{13}$ and the State which has legal obligations under the Convention. As the Chamber noted, "sponsorship... is to achieve the result that the obligations set out in the Convention, a treaty under international law which binds only States Parties thereto, are complied with by entities that are subjects of domestic legal systems". ${ }^{14}$ Although this is a general point of international law, and cannot be said to raise anything particular about international environmental law or sustainable development, the requirement of sponsorship is at least a reminder of an alternative means by which private entities can be brought within the framework of the international rule of law. ${ }^{15}$ Although, as with much of the regulation of the Area, one must be careful not to extrapolate too broadly from the undoubted sui generis nature of this particular regime, the relationship between the "sponsor" and the "sponsored" does highlight the capacity of the international community to develop creative and innovative mechanisms of control, when necessary. There is, however, one aspect of the sponsorship relationship that this article will refer to later, which ties very closely to the principle of good governance in the New Delhi

${ }^{13}$ It was fundamental for the Chamber to define accurately what is meant by "activities in the area" (Advisory Opinion, paragraphs 82-97). Although the LOSC provides a broad definition: "all activities of exploration for, and exploitation of, the resources of the Area" (LOSC Article $1(1)(3))$, this leaves much undetermined. The Chamber was assisted by definitions of 'exploration' and 'exploitation' in the 2000 and 2010 Regulations (paragraphs 89-90). In addition, the Chamber came to the view that whilst certain supplementary activities such as lifting the minerals to the surface, "shipboard processing" (paragraph 88), "evacuation of water from the minerals and the preliminary separation of materials of no commercial interest, including their disposal at sea" (paragraph 95) and ship-to-ship transfer (where the former lifts the minerals and the latter undertakes certain preliminary processing) all fell within the definition, transportation of the minerals to port and land-based processing did not. In coming to its judgment, the Chamber was influenced by not wishing to create potential conflicts with the rules of other maritime regimes (e.g., high seas), whilst at the same time ensuring that activities closely connected to the initial exploration/exploitation activity, and which indeed presented some of the most significant risks to the marine environment, would come within the remit of the Authority's rules (paragraph 97).

${ }_{14}$ Advisory Opinion, paragraph 75.

15 The responsibilities of private/commercial actors, and how to encourage their compliance with international rules of good conduct, have been very much at the forefront of recent discussions on corporate social responsibility, as is shown by the 2011 Report of the Special Representative of the Secretary-General on the issue of human rights and transnational corporations and other business enterprises: Guiding Principles on Business and Human Rights: Implementing the United Nations "Protect, Respect and Remedy" Framework (A/HRC/17/31, 21 March 2011); http://www.ohchr.org/documents/issues/business/A.HRC.17.31.pdf (last accessed: August 2011). 
Declaration, and that is how the sponsoring State should regulate the sponsored entity, and, more specifically, whether that should be through private or public law.

\section{The Seabed Disputes Chamber and Advisory Opinion Procedure}

Before considering the substance of the Advisory Opinion itself, a few words on the Seabed Disputes Chamber and the process that it followed in this particular case seem appropriate. The Chamber is established by virtue of LOSC Article 186, as amplified by Article 14 and section 4 of Annex VI thereto. The jurisdiction of the Chamber is notably different from the ITLOS (from which it is a "separate judicial body"), ${ }^{16}$ including the jurisdiction to resolve contentious disputes not only between States Parties inter se and between States Parties and the Authority but also, in certain instances, between the Authority and prospective contractors, State enterprises or sponsored entities. ${ }^{17}$ It is significant that the Chamber also has the authority to hand down advisory opinions, if requested to do so by the Council or Assembly of the International Seabed Authority. ${ }^{18}$ Indeed, there was some discussion before the Chamber whether in this regard it was different from the International Court of Justice (ICJ), which has the discretion whether to respond positively to a request for an advisory opinion; it was noted that advisory opinions from the Chamber "shall be given as a matter of urgency". ${ }^{19}$ The Chamber itself did not address the issue of whether it had discretion in this regard, noting that in this particular instance, it was in any event answering the questions put to it. ${ }^{20}$

But equally interesting is the reference to urgency, which the Chamber seems to have taken to its heart, particularly when one notes that the request from the Council was made in May 2010, oral hearings were held in September and the Advisory Opinion was released the following February. Perhaps it is no wonder, therefore, that the Chamber noted that " $[t]$ he functions of the Chamber... are relevant for the good governance of the Area", going on to point out "by answering the questions it will assist the Council in the performance of its activities and contribute to the implementation of the Convention's regime". ${ }^{21}$ Although somewhat a sine qua non, this aspect of good

\footnotetext{
${ }^{16}$ Advisory Opinion, paragraph 25.

17 Article 187 LOSC.

18 Article 191 LOSC.

19 Emphasis added.

${ }^{20}$ Advisory Opinion, paragraph 48.

${ }^{21}$ Ibid., paragraphs 29-30.
} 
governance of natural resource management is easily forgotten, namely the role of judicial bodies to utilise general principles and the rule of law both to resolve disputes (i.e., its contentious jurisdiction) ${ }^{22}$ and, as in the present Advisory Opinion, to assist political bodies in the accomplishment of their duties by acting as an "independent and impartial body". 23

There was a great deal of interest in this Advisory Opinion: twelve States, the International Seabed Authority, two intergovernmental organisations ${ }^{24}$ and the United Nations Environment Programme (UNEP) submitted written statements. At the hearings, the Authority, nine States and the two intergovernmental organisations made oral statements. In addition, two non-governmental organisations (World Wide Fund for Nature and Greenpeace International) submitted a written statement and a request to participate as amici curiae. The written statement was not accepted as it fell outside Article 133 of the Tribunal's Rules of Procedure, which limits such involvement to intergovernmental organisations. Nevertheless, although the statement was not formally included within the case file, it was posted on the Tribunal's website and the Authority and participating States Parties and intergovernmental organisations were duly informed of its existence. ${ }^{25}$ Separately, the non-governmental organisations were notified that the Chamber had decided not to allow them to participate in oral proceedings. ${ }^{26}$ This reflects the traditional understanding of the (non-)role of non-governmental organisations in general international dispute settlement and advisory jurisdiction. Although it might be considered regressive in light of (admittedly sometimes limited) developments in other fields, namely trade and investment disputes, ${ }^{27}$ the rather creative means by which the written statement was brought to the attention of the participating States and organisations should be noted. But of course, this (at best) informal status prevented meaningful use of its contents,

22 T. Stephens, 'Sustainability Discourses in International Courts: What Place for Global Justice?’ in: D. French (ed.), Global Justice and Sustainable Development (Leiden/Boston, Martinus Nijhoff, 2010) 56: "Fairness and justice, notions that underlie not only sustainability, but also principles of equity that have long been applicable in the resolution of disputes over natural resources...there remain many opportunities for their deployment to resolve fractious disputes over natural resources at a time of growing scarcity and accelerating environmental degradation".

${ }^{23}$ Advisory Opinion, paragraph 26.

${ }_{24}$ Namely, the Interoceanmetal Joint Organization and the International Union for Conservation of Nature (IUCN).

${ }_{25}$ Advisory Opinion, paragraph 13.

${ }_{26}$ Ibid., paragraph 14.

27 See, for instance, K. Tienhaara, 'Third Party Participation in Investment-Environment Disputes: Recent Developments' (2007) 16 Review of European Community and International Environmental Law 230. 
unless it was 'picked up' and used by one of the formal participants. In light of how substantively progressive the Advisory Opinion is in many respects, it is perhaps unfortunate that procedurally the international judicial community still has some way to go, especially as other tribunals have begun to accept amicus curiae briefs.

\section{Applicable Law, Interpretation and Remit of the Advisory Opinion}

Two final preliminary issues are worth briefly mentioning. The first is the matter of applicable law and interpretation. The Convention and ITLOS's Statute set out the applicable law, which include the 1982 Convention, the 1994 Implementation Agreement, rules and regulations lawfully adopted by the Authority and "other rules of applicable law not [otherwise] incompatible". ${ }^{28}$ Of particular significance were the 'rules and regulations' promulgated by the Authority, to be considered as secondary legislation, although equally binding on the States Parties. These were the 2000 Regulations on Prospecting and Exploration for Polymetallic Nodules in the Area and the 2010 Regulations on Prospecting and Exploration for Polymetallic Sulphides in the Area. ${ }^{29}$ The Chamber relies upon the reasoning of the ICJ's 2010 Advisory Opinion on the unilateral declaration of independence in respect of Kosovo ${ }^{30}$ to come to the view that the interpretation provisions of the 1969 Vienna Convention on the Law of Treaties, which it had just noted were reflective of custom (something the ITLOS itself had never expressly done), "may, by analogy, provide guidance" to the interpretation of legally binding documents, which nevertheless are not treaties. ${ }^{31}$ As will become evident, this was not the only time

\footnotetext{
28 Article 293(1) LOSC.

29 These regulations, together with other relevant rules, will together form part of what is referred to as the 'mining code'. The Authority says that "The 'Mining Code' refers to the whole of the comprehensive set of rules, regulations and procedures issued by the International Seabed Authority to regulate prospecting, exploration and exploitation of marine minerals in the international seabed Area"; http://www.isa.org.jm/en/documents/mcode (last accessed: July 2011).

${ }^{30}$ Accordance with international law of the unilateral declaration of independence in respect of Kosovo (Judgment of 22 July 2010, paragraph 94); http://www.icj-cij.org/docket/files/ 141/15987.pdf (last accessed: August 2011).

${ }^{31}$ Advisory Opinion, paragraph 60. Nevertheless, it is important and relevant here to note that the International Court of Justice (ICJ) goes on to say that "Security Council resolutions are issued by a single, collective body and are drafted through a very different process than that used for the conclusion of a treaty. Security Council resolutions are the product of a voting process as provided for in Article 27 of the Charter, and the final text of such resolutions represents the view of the Security Council as a body" (paragraph 94).
} 
that the Chamber relies—and builds upon - the reasoning of other courts and tribunals, most notably the ITLOS and the ICJ.

The final preliminary issue is the questions that the Council sought answers to. In summary form, they were as follows: (i) what are the responsibilities and obligations of sponsoring States under the regime established by LOSC Part $\mathrm{XI}$ and the 1994 Implementation Agreement? (ii) what is the extent of the liability of sponsoring States for a failure of a sponsored entity to comply with relevant provisions? Finally, (iii) what measures must a sponsoring State undertake to fulfil its responsibilities under the Convention? All three questions are intimately related, as determining the necessary measures to be taken (in answering question 3) will both contribute to whether the sponsoring State has met its obligations under the Convention (question 1) and thus whether it has exemption against liability for any damage caused (question 2). As befitting a judicial chamber, the Chamber limited itself largely to answering the questions asked and did not range too broadly in its judicial role. Nevertheless, in answering these questions, the Chamber makes a number of more general comments, which supports a finding that the Advisory Opinion is of broader relevance. Of particular importance are its remarks on the 'obligation to ensure', otherwise referred to as due diligence, on the precautionary approach and on enforcing community interests, including seemingly to affirm the putative existence of actio popularis (a claim brought on behalf of the international community) in this area of the law.

\section{The Advisory Opinion: a 'Sustainable Development' Judgment?}

Before considering the substance of the Advisory Opinion and the extent to which it deals with particular principles and themes of sustainable development, it is useful to consider briefly the question whether this really is a 'sustainable development' case, thus bringing into sharp focus the normative relationship between international law on sustainable development and other areas of international law. ${ }^{32}$ As already noted, the phrase 'sustainable development' is not referenced in the Advisory Opinion, ${ }^{33}$ which may come as little

\footnotetext{
32 See D. French, International Law and Policy of Sustainable Development (Manchester, Manchester University Press, 2005) 37: "It is quite clear that the legal implications of sustainable development are not restricted to international environmental law stricto sensu, though neither is there much value in treating the concept as an all-embracing term to cover the whole terrain presently covered by, inter alia, international environmental, economic, trade and social law".

33 But note Advisory Opinion, paragraph 159: "the highest standards of protection of the marine environment, the safe development of activities in the Area and protection of the common heritage of mankind".
} 
surprise, as so far the concept has found limited expression within the texts and discussions on the Area. This silence, of course, is not determinative, as that has not prevented other judicial tribunals in utilising this and other cognate concepts relatively liberally. ${ }^{34}$ However, the generic idea of 'development', in contrast to the perhaps more technical notion of sustainable utilisation of natural resources, has generally been conceptually restricted to areas within a State's territory, or at least its jurisdiction, e.g., the exclusive economic zone, and has rarely been discussed in relation to global areas, such as the deep seabed beyond national jurisdiction..$^{35}$ Although the 1987 World Commission's report, Our Common Future, which initiated the current sustainable development discourse, mentioned the deep seabed ${ }^{36}$ the 1992 inter-governmental plan of action, Agenda 21, did not. Sustainable development is thus still very much perceived primarily in terms of endogenous economic growth and its linkage to social improvement. When oceans are considered, it is usually from either a fisheries/food security perspective or because of concerns relating to marine pollution from ship-based or land-based sources. ${ }^{37}$

Although the governance of the Area has rarely been understood by reference to sustainable development, the role of the Authority in managing the natural resources of the deep seabed to contribute to socio-economic

${ }^{34}$ For instance, Arbitration regarding the Iron Rhine ('jjeren Rijn') Railway between The Kingdom of Belgium and The Kingdom of The Netherlands (The Hague, 24 May 2005) paragraph 58: "There is considerable debate as to what, within the field of environmental law, constitutes 'rules' or 'principles'; what is 'soft law'; and which environmental treaty law or principles have contributed to the development of customary international law... The emerging principles, whatever their current status, make reference to conservation, management, notions of prevention and of sustainable development, and protection for future generations"; http://pcacpa.org/upload/files/BE-NL\%20Award\%20240505.pdf (last accessed: August 2011).

35 Cf. Convention on Biological Diversity-COP 8 Decision VIII/21: "Marine and coastal biological diversity: conservation and sustainable use of deep seabed genetic resources beyond the limits of national jurisdiction", paragraph 1: "Notes that deep seabed ecosystems beyond the limits of national jurisdiction... contain genetic resources of great interest for their biodiversity value and for scientific research as well as for present and future sustainable development and commercial applications" (emphasis added); http://www.cbd.int/decision/cop/?id=11035 (last accessed: August 2011).

36 World Commission on Environment and Development, Our Common Future (Oxford, Oxford University Press, 1987) 273: "Over 45 per cent of the planet's surface, this sea-bed area and its resources are declared to be the 'common heritage of mankind', a concept that represents a milestone in the realm of international co-operation".

37 Plan of Implementation of the 2002 World Summit on Sustainable Development, paragraph 30: "Oceans, seas, islands and coastal areas form an integrated and essential component of the Earth's ecosystem and are critical for global food security and for sustaining economic prosperity and the well-being of many national economies, particularly in developing countries"; http://www.un.org/esa/sustdev/documents/WSSD_POI_PD/English/POIToc.htm (last accessed: August 2011). 
development within environmental limits will undoubtedly be strengthened by this Advisory Opinion. In particular, the Chamber is keen to stress, in addition to the imperative of the protection of the marine environment, the developmental—in contrast to the purely commercial—objective of the Area. The following quotation is of singular importance and worth quoting in full:

It should be pointed out that...the Convention emphasizes that the achievement of the goals of the Convention will "contribute to the realization of a just and equitable international economic order which takes into account the interests and needs of mankind as a whole and, in particular, the special interests and needs of developing countries, whether coastal or landlocked" ... article 148 of the Convention speaks about the promotion of the effective participation of developing States in activities in the Area. What is more important is that Annex III, article 9, paragraph 4, of the Convention specifically refers to the right of a developing State or any natural or juridical person sponsored by it and effectively controlled by it, to inform the Authority that it wishes to submit a plan of work with respect to a reserved area. These provisions have the effect of reserving half of the proposed contract areas in favour of the Authority and developing States. Together with [other provisions] they require effective implementation with a view to enabling the developing States to participate in deep seabed mining on an equal footing with developed States. ${ }^{38}$

Thus, as noted in the introduction, it is by no means hyperbolic to see the Advisory Opinion as not only supporting sustainable development at a general level but, more than that, in actually seeking to address various emerging normative aspects of the concept. To assist in this regard, the ILA's $2002 \mathrm{New}$ Delhi Declaration of Principles of International Law relating to Sustainable Development is used in this article to help frame the analysis. ${ }^{39}$ It is arguably the most prominent text on the legal implications of sustainable development, despite its non-governmental nature. The Declaration contains seven principles, which are set out below: (i) the duty of States to ensure sustainable use of natural resources, (ii) equity and the eradication of poverty, (iii) common but differentiated responsibilities, (iv) the precautionary approach, (v) participation, (vi) good governance, and (vii) integration and interrelationship. The remainder of this article will not provide a comprehensive analysis of how the Chamber references these principles, but will rather focus on what the Chamber had to say on four of them, namely the sustainable use of natural resources, the precautionary approach, common but differentiated responsibilities, and good governance. This is not an attempt to pigeon-hole the many

38 Advisory Opinion, paragraph 163.

39 ILA Resolution 3/2002, Annex as published as UN Doc. A/57/329 (2002); http://www .ila-hq.org/en/committees/index.cfm/cid/25 (last accessed: August 2011). 
issues the Chamber addresses artificially within certain "sustainable development" principles, but rather to group together cognate matters and highlight how the Advisory Opinion has arguably made a significant and substantive contribution to the broader jurisprudence on international environmental law, the emerging field of international law on sustainable development and indeed general international law.

\section{The Duty of States to Ensure Sustainable Use of Natural Resources}

The duty of States to ensure the sustainable use of natural resources, as framed by the ILA, is a broad notion, reflecting a number of inter-connected obligations in international law, some of which are settled (namely, Principle 21 of the 1972 Stockholm Declaration on the Human Environment, cited below) and others which remain nascent and contested (namely, that States should manage their 'territorial' natural resources sustainably). The New Delhi Declaration expressly references the resources of the deep seabed, amongst other areas, as the common heritage of mankind. Nevertheless, beyond endorsing certain fundamental ideas - including, albeit of less relevance here, the common concern of humankind ${ }^{40}$ - it is widely accepted that the general obligation to sustainably use natural resources is heavily context-dependent, and much detail is left to international treaties and other instruments and/or domestic legislation..$^{41}$ Moreover, in responding to the questions put to it, the Chamber does not directly address the question as to what standards a sponsored contractor must adhere. Rather, it focuses upon the obligations of the sponsoring State in ensuring compliance by the contractor with its commitments - these being variously found in "its contract and its obligations under this Convention", ${ }^{42}$ which must equally be taken to include the Regulations lawfully adopted by the Authority, as well as other rules and procedures of the Authority.

In light of this, this section of this article focuses upon three incidental aspects of the general obligation of sustainable use, relating specifically to the responsibilities of the sponsoring State. These are as follows. First: what the

${ }^{40}$ New Delhi Declaration, paragraph 1.3: "The protection, preservation and enhancement of the natural environment, particularly the proper management of climate system, biological diversity and fauna and flora of the Earth, are the common concern of humankind".

${ }^{41}$ P. Birnie, A. Boyle and C. Redgwell, International Law and the Environment (Oxford, Oxford University Press, 2009, 3rd ed.) 200-201: "little of value can be inferred from a broad principle of sustainable use without reference to state practice and the practice of international organizations".

${ }^{42}$ LOSC Annex III, Article 4, paragraph 4. 
Convention refers to as the sponsoring State's "responsibility to ensure" that the contractor meets its own commitments, which the Chamber rightly characterises as an obligation of due diligence. Second: the obligation to require the undertaking of an environmental impact assessment (EIA) and monitoring thereafter. Third: recognition of the universal nature of regulating activities in the Area, thus justifying a high level of cooperation, emergency assistance and, a matter of importance of general international law, the right to bring claims for damage arising from activities in the Area. As became apparent from the Chamber's reasoning, there is a synergy between regulation of the deep seabed and general international law. Not only does the Chamber find support for its views on how the Area should be regulated from other aspects of international law (and from other tribunals, notably the ICJ), but in equal measure, what the Chamber has to say on the Area—and how it says it—is of significance, more broadly. This two-way process of reasoning is of central importance in promoting the general value of the Advisory Opinion to a wider audience, beyond those specially interested in the governance of the deep seabed.

\section{"Responsibility to Ensure": Obligation of Due Diligence}

The central question that the Chamber was called upon to answer was: what is required of a sponsoring State in ensuring a sponsored contractor meets its own commitments in relation to activities in the Area. The Chamber notes that the Convention places a sponsoring State under the "responsibility to ensure that activities in the Area... shall be carried out in conformity" with the regime. ${ }^{43}$ The Chamber characterises this obligation as a means-or a "mechanism"- by which the rules of the regime "become effective" for private contractors and which will ultimately "find their legal basis in domestic law". ${ }^{44}$ As the Chamber notes, the "responsibility to ensure" is relied upon when, although the traditional principle of State responsibility for private behaviour (namely, that the actions of a private individual are not attributable to the State $)^{45}$ is "not considered satisfactory", the notion that the State would be

\footnotetext{
${ }^{43}$ Article 139 LOSC.

${ }_{44}$ Advisory Opinion, paragraph 108.

452001 Articles on State Responsibility, commentary to Article 8 (Report of the International Law Commission on the work of its Fifty-Third Session, 47; http://untreaty.un.org/ilc/ publications/yearbooks/contents/2001_v1_e.pdf: "As a general principle, the conduct of private persons or entities is not attributable to the State under international law. Circumstances may arise, however, where such conduct is nevertheless attributable to the State because there exists a specific factual relationship between the person or entity engaging in the conduct and the State".
} 
held responsible for "each and every violation" 46 by a private actor would equally be the wrong response to the situation. In other words, neither the laissez faire nor the complete attribution approach is appropriate; however, what is justifiable "is an obligation to deploy adequate means, to exercise best possible efforts, to do the utmost, to obtain this result". ${ }^{47}$ As the Chamber notes, it is an obligation of conduct, not of result, and in increasingly common legal usage, it is "an obligation of 'due diligence'". 48 The Chamber relies upon the commentary to the International Law Commission's (ILC) 2001 Articles on Prevention of Transboundary Harm from Hazardous Activities to substantiate this finding: "It is the conduct of the State of origin that will determine whether the State has complied with its obligation". ${ }^{49}$

The idea that States are required to exercise regulatory diligence to ensure private actors meet a certain level of behaviour is neither new nor certainly not unique to this area of the law. It is an idea that has a long history in international law, most famously expressed by the ICJ in the Corfu Channel case. ${ }^{50} \mathrm{It}$ is significant that it has become accepted as the normative standard on States for compliance with Principle 21 of the Stockholm Declaration, accepted as customary law, which imposes upon them 'the responsibility to ensure that activities within their jurisdiction or control do not cause damage to the environment of other States or of areas beyond the limits of national jurisdiction'. ${ }^{51}$ The ties of nationality and effective control required for sponsorship in relation to the Area (as already discussed) thus provide the necessary legal link for reasons of jurisdiction with the sponsoring State. The Chamber, whilst not directly quoting either the Corfu Channel decision or the Stockholm Declaration (or the similar provision at Principle 2 of the 1992 Rio Declaration), does

46 Advisory Opinion, paragraph 112.
47 Ibid., paragraph 110.
48 Ibid.
${ }_{49} 2001$ Articles on Transboundary Harm, commentary to Article 3 (ILC, supra note 45, 154). Technically, the Articles do not apply to common areas as 'transboundary harm' is narrowly defined as: "'Transboundary harm' means harm caused in the territory of or in other places under the jurisdiction or control of a State other than the State of origin, whether or not the States concerned share a common border" (152). Nevertheless, the discussion of due diligence is undoubtedly reflective of the requirements on States under the broader obligation to be found in customary law, on which see below.

50 Judgment of 9 April 1949 (Merits), ICJ Reports (1949) 4, 22: "not to allow knowingly its territory to be used for acts contrary to the rights of other States".

${ }^{51}$ See also Advisory Opinion on the Legality of the Threat or Use of Nuclear Weapons, ICJ Reports (1996) 226, 241-242: "The existence of the general obligation of states to ensure that activities within their jurisdiction and control respect the environment of other states and of areas beyond national control is now part of the corpus of international law relating to the environment". 
refer to LOSC Article 194(2), which codified Principle 21 in the context of the law of the sea, to support its analysis.

What the Chamber does rely on, however, is the recent judgment of the ICJ in Case concerning Pulp Mills on the River Uruguay (2010) to cement this connexion between "responsibility to ensure" and due diligence. Although the case concerned a dispute between Uruguay and Argentina over a shared transboundary watercourse, nevertheless the Chamber finds the reasoning highly persuasive. Indeed, this is a judgment the Chamber relies on significantly at various points in the Advisory Opinion. Whilst each case is bounded by its own facts and applicable law, there is no doubt that the Chamber finds benefit in placing the sponsoring State's duties within the broader customary framework outlined by the ICJ. In particular, the quoted part of the Pulp Mills judgment is illuminating here because it highlights the comprehensive nature of due diligence, an issue that the Chamber itself picks up later in the Advisory Opinion. As the ICJ notes: "It is an obligation which entails not only the adoption of appropriate rules and measures, but also a certain level of vigilance in their enforcement and the exercise of administrative control... such as the monitoring of activities" ${ }^{52}$ Such pro-activity is something that the Chamber clearly expects from sponsoring States in regulating all stages of activities in the Area.

If the conflation of the "responsibility to ensure" and due diligence is largely unsurprising, the Chamber's understanding of what is required of a sponsoring State in meeting its due diligence obligation is worthy of more reflection. Building upon the general understanding of due diligence, the Chamber emphasises the factual nature of the obligation, noting that it "may not easily be described in precise terms... 'due diligence' is a variable concept". ${ }^{33}$ The Chamber emphasises a range of factors that might affect what is required of sponsoring States and thus vary the level of due diligence expected. First, the general state of knowledge will be constantly shifting-improving-because of fresh insights and new information. As it said, "measures considered sufficiently diligent at a certain moment may become not diligent enough in light... of new scientific or technological knowledge". ${ }^{54}$ Second, the level of due diligence will depend upon the nature of the risks and, related to this, the nature of the activities undertaken. Prospecting is usually less likely to cause damage than exploration, which similarly has fewer risks attached than

\footnotetext{
52 Judgment of 20 April 2010, paragraph 197; http://www.icj-cij.org/docket/files/135/15877 .pdf (last accessed: August 2011); hereinafter: Pulp Mills.

53 Advisory Opinion, paragraph 117.

${ }^{54}$ Ibid.
} 
exploitation. ${ }^{55}$ Third, the risks may vary depending upon the precise minerals subject to mining activity. Thus, in what must be a general truism of relevance to the regulation of any potentially hazardous activity, and certainly builds upon the work of the ILC in this field, ${ }^{56}$ the Chamber notes that "[t]he standard of due diligence has to be more severe for the riskier activities". ${ }^{57}$

A final aspect of due diligence, and one which is central to how the Chamber seeks to draw together the various normative seams in the regime, is to relate the due diligence obligation of sponsoring States, on the one hand, to what it refers to as its direct obligations under the Convention and the Regulations, on the other. These direct obligations exist for sponsoring States independently of ensuring contractors comply with their obligations. Such obligations include the obligation to respect the precautionary approach, to support and require EIA and best environmental practices, and to support the Authority both generally and in emergencies. Although each is an autonomous obligation within the governance of the regime, and States will be held accountable accordingly for breaches thereof, nevertheless the Chamber is equally clear as to their relationship with the broader duty of due diligence. As it says, "compliance with these obligations can also be seen as a relevant factor in meeting the due diligence 'obligation to ensure' and that the said obligations are in most cases couched as obligations to ensure compliance with a specific rule". ${ }^{58}$ The significance of this statement should not be easily dismissed. For reasons explained below, not only does this incorporate within the due diligence obligation requirements that were not otherwise extant in the Convention at the time of its adoption, but equally it enriches due diligence and highlights the integrated and over-arching nature of the obligation. As a question of fact, it is surely correct that due diligence should not be compartmentalised and segregated from other relevant provisions, but rather should be informed by them. While the Chamber is less clear on how this integration of obligations is to occur-as will be noted, when discussing best environmental practices in this context, the Chamber adds the important qualifier "in general terms" - such integration does reinforce the due diligence obligation. As a question of fact, whether the level of regulatory behaviour undertaken by

\footnotetext{
55 Ibid.

562001 Articles on Transboundary Harm, commentary to Article 3 (ILC, supra note 45, 154): "The standard of due diligence against which the conduct of the State of origin should be examined is that which is generally considered to be appropriate and proportional to the degree of risk of transboundary harm in the particular instance. For example, activities which may be considered ultrahazardous require a much higher standard of care in designing policies and a much higher degree of vigour on the part of the State to enforce them".

${ }_{57}$ Advisory Opinion, paragraph 117.

58 Ibid., paragraph 123.
} 
any sponsoring State meets the due diligence obligation is inherently difficult to assess and prone to subjective interpretation. Nevertheless, due diligence is also a legal issue and the Chamber has set a reasonably clear benchmark of what it expects of sponsoring States.

\section{Environmental Impact Assessment: The New Environmental Customary Norm}

One particular aspect of especial importance to the Chamber is the requirement of an EIA. The Chamber recognises that the sponsoring State is under a due diligence obligation to ensure a potential contractor undertakes such an assessment prior to the submission of an application for a plan of work to the Authority. Moreover, as the Chamber notes, the Regulations equally impose a direct obligation on sponsoring States (and contractors) to work with the Authority to ensure the "establishment and implementation of programmes for monitoring and evaluating the impacts of deep seabed mining on the marine environment". 59 The inclusion of environmental monitoring ensures the obligation extends beyond the pre-approval stage to during and after such activities. Indeed, due to the remote nature of the environment in question, while the application of a plan of work requires a "preliminary" assessment of the impact of the activities on the marine environment, ${ }^{60}$ it is arguably the ongoing monitoring that provides the more effective safeguard:

The Contractor shall, in accordance with the Regulations, gather environmental baseline data as exploration activities progress and develop and shall establish environmental baselines against which to assess the likely effects of the Contractor's activities on the marine environment. The Contractor shall, in accordance with the Regulations, establish and carry out a programme to monitor and report on such effects on the marine environment. The Contractor shall cooperate with the Authority in the implementation of such monitoring. ${ }^{61}$

Although such provisions are vital, the Chamber, conscious that the Nodules and Sulphides Regulations are per se limited in terms of the scope of activities they cover, is also clear in seeking to provide for a more comprehensive remit

\footnotetext{
59 Advisory Opinion, paragraph 142.

${ }_{60}$ Nodules Regulations, Annex 2, paragraph 24(c).

${ }_{61}$ Nodules Regulations, Annex 4, paragraphs 5.2 and 5.3 (emphasis added). See also paragraph 5.5: "Prior to the commencement of testing of collecting systems and processing operations, the Contractor shall submit to the Authority: (a) A site-specific environmental impact statement".
} 
for EIA and monitoring. Thus it emphasises both the conventional ${ }^{62}$ and customary obligation of EIA, which together extend the requirement to undertake EIA significantly beyond the confines of the Regulations. Again the Chamber relies heavily upon the judgment of the ICJ in Pulp Mills for its reasoning. Whilst recognising the particular characteristics of that casetransboundary, shared freshwater resources - the Chamber is convinced as to its overall utility in this regard. Indeed, the Chamber takes a number of points from it. First, it finds EIA to be a rule of customary law, which the ICJ also did-in that case concerning a shared watercourse. ${ }^{63}$ However, as the Chamber notes: "The Court's reasoning in a transboundary context may also apply to activities with an impact on the environment in an area beyond the limits of national jurisdiction; and the Court's references to 'shared resources' may also apply to resources that are the common heritage of mankind". ${ }^{64}$

Second, the Chamber uses this newly declared rule of custom to bring within the remit of EIA other "activities... even beyond the scope of the Regulations". ${ }^{65}$ Specifically, the Chamber is of the view that "EIAs should be included in the system of consultations and prior notifications set out in article 142 of the Convention with respect to 'resource deposits in the Area which lie across limits of national jurisdiction" " ${ }^{66}$ This is undoubtedly obiter in terms of the Advisory Opinion - there was no need to discuss these particular activities-nevertheless, the Chamber's finding of EIA to be a customary rule has allowed it to make more general claims.

Finally, the Chamber relies upon the ICJ to avoid having to be too precise about the contents of EIAs. As the ICJ itself carefully noted, the rule of custom in this area does not "specify the scope and content of an environmental impact assessment". ${ }^{67}$ Of course, as regards those activities in the Area governed by the Regulations-as well as the 2002 Recommendations for the

${ }^{62}$ Article 206 LOSC: "When States have reasonable grounds for believing that planned activities under their jurisdiction or control may cause substantial pollution of or significant and harmful changes to the marine environment, they shall, as far as practicable, assess the potential effects of such activities on the marine environment and shall communicate reports of the results of such assessments...”.

${ }^{63}$ Pulp Mills, paragraph 204: "a practice, which in recent years has gained so much acceptance among States that it may now be considered a requirement under general international law to undertake an environmental impact assessment". For general discussion on transboundary EIA, although prior to the International Court's judgment in this case, see K. Bastmeijer and T. Koivurova (eds.), Theory and Practice of Transboundary Environmental Impact Assessment (Leiden, Martinus Nijhoff, 2008).

${ }^{64}$ Advisory Opinion, paragraph 148.

${ }^{65}$ Ibid.

${ }^{66}$ Ibid.

67 Pulp Mills, paragraph 205. 
Guidance of the Contractors for the Assessment of the Possible Environmental Impacts Arising from Exploration for Polymetallic Nodules in the Area ${ }^{68}$ there is much more detail to guide sponsoring States and contractors. But the Chamber is equally clear that lack of precision or guidance is not a reason not to give effect to this customary obligation and reiterates almost pointedly that the requirement of EIA exists "beyond the scope of application of specific provisions of the Regulations". ${ }^{69}$

\section{The Common Heritage of Mankind}

Much of the stringency of the tone of the Advisory Opinion is affected by the importance the Chamber gives to the Area as a common heritage of mankind, which elevates these particular natural resources, and this particular geographical region, to a special position in international law. As the Chamber states, "the role of the sponsoring State is to contribute to the common interest of all States in the proper implementation of the principle of the common heritage of mankind". ${ }^{70}$ This is a good example of what occurs throughout the Advisory Opinion, where the reasoning and rhetoric of common heritage infuse and strengthen the Chamber's thinking. Of particular interest in this regard are the Chamber's views on who can bring a claim against a sponsoring State in breach of its obligations under the regime. The Convention is silent on this matter, in contrast to an express provision relating to sponsored contractors for which the sponsoring State must ensure and enact appropriate recourse to compensation in domestic law. ${ }^{71}$ On the question on the liability of sponsoring States, however, the Chamber is left with little guidance in the Convention or Regulations and turns to general international law. Although on such

${ }^{68}$ See, in particular, paragraph 5: "These recommendations for Guidance of Contractors describe the procedures to be followed in the acquisition of baseline data, and the monitoring to be performed during and after any activities in the exploration area with potential to cause serious harm to the environment. Their specific purposes are: (a) To define the biological, chemical, geological and physical components to be measured and the procedures to be followed by contractors to ensure effective protection for the marine environment from harmful effects which may arise from the contractors' activities in the Area...”. Despite the Chamber referencing the 2002 Recommendations, they were amended slightly at the sixteenth session of the Authority (2010), and will thus likely be referred to in the future as the 2010 Recommendations.

69 Advisory Opinion, paragraph 150.

70 Ibid., paragraph 226.

71 Article 235(2) LOSC: "States shall ensure that recourse is available in accordance with their legal systems for prompt and adequate compensation or other relief in respect of damage caused by pollution of the marine environment by natural or juridical persons under their jurisdiction". 
an important issue some may criticise the Advisory Opinion for lacking precision, this may be unfair criticism as the regime itself is itself silent on the matter. The Chamber "envisage[s"] that the type of damage compensable in such an instance would include damage to the Area and damage to the marine environment. ${ }^{72}$ It also speculates that claims could be made by coastal States (presumably under international law for any harm caused to a directly injured State) and "entities engaged in deep seabed mining" (although the basis of this claim is less clear, potentially contractual or even tortious). ${ }^{73}$

What is remarkable however, is the Chamber's next step, filling a gap in both conventional and customary law. First, the Chamber determines that the Authority is itself entitled to make a claim - notwithstanding a lack of authority in the Convention-presumably on the basis of implied powers of the Authority ${ }^{74}$ so as to give effect to its responsibilities to act "on behalf" of mankind as clearly referenced in the Convention. ${ }^{75}$ Moreover, the Chamber believes each State Party should be able to bring a claim against a sponsoring

72 Advisory Opinion, paragraph 179.

${ }^{73}$ Mention should also be made of potential harm to the interests of third parties involved in other marine activities, such as cable laying or fishing. See Article 147(1) LOSC: "Activities in the Area shall be carried out with reasonable regard for other activities in the marine environment".

${ }^{74}$ On the theory of the implied powers of international organisations, and in particular in contrast to the more controversial notion of inherent powers, see V. Engström, 'Powers of Organizations and the Many Faces of Autonomy' in: R. Collins and N. White (eds.), International Organizations and the Idea of Autonomy (London, Routledge, 2011) 213-229.

75 As only State Parties to the LOSC are entitled to sponsor contractors in the Area, the contentious question of the Authority acting as 'injured party' against a non-member does not arise. What is interesting are the potential implications of the Advisory Opinion for future harm caused by the yet to be established Enterprise (the operational arm of the Authority). LOSC Annex IV, Article 2 states that "the Enterprise shall enjoy autonomy in the conduct of its operations" whilst Article 3 of the same Annex goes on to provide: "Nothing in this Convention shall make the Enterprise liable for the acts or obligations of the Authority, or make the Authority liable for the acts or obligations of the Enterprise". Nevertheless, can an organ of an international organisation claim against another organ? While this may be a theoretically interesting debate, reference should also be made to Article 170(2) LOSC: "The Enterprise shall act in accordance with this Convention and the rules, regulations and procedures of the Authority", Annex III, Article 22: "the Authority shall have responsibility or liability for any damage arising out of wrongful acts in the exercise of its powers and functions", as well as the fact that the Enterprise can only undertake projects once a plan of work-i.e., a contract-has been agreed with the Authority (Annex IV, Article 12). In short, the Enterprise would arguably not only be directly obliged to respect the rules of the Area, including making reparation for harm caused, but would also be contractually obliged to do so, as shown by the standard clauses on responsibility and liability annexed to the Regulations. Presumably a request for an advisory opinion from the Seabed Disputes Chamber to determine the extent of liability might be a way forward in such a situation. 
State in breach to recover damages. The Chamber relies upon the argument that the obligations to protect the environment of the high seas and in the Area are of "erga omnes character"76-obligations opposable to the whole world, and in which the whole world has an interest. Although this is an assumption that many commentators would readily hold in relation to these areas of res communis and common heritage respectively, rarely - if ever-has it been said in judicial proceedings. ${ }^{77}$ Nevertheless, on the basis of this finding, the Chamber is confident that all States Parties have such a legal interest. To reinforce this view, the Chamber relies upon the International Law Commission's 2001 Articles on State Responsibility, and especially Article 48 which provides such a right to invoke responsibility to "[a]ny State other than an injured State" ${ }^{78}$ It was generally felt that Article 48 was a progressive development, rather than a codification, of existing law when included in the 2001 Articles. ${ }^{79}$ The Advisory Opinion will thus certainly assist in cementing its position in international law, notwithstanding the many remaining questions surrounding it. However, the potentially radical claims made by the Chamber should not be lost here- the finding of erga omnes obligations, the affirmation of essentially what would be an actio popularis in international environmental law, ${ }^{80}$ and the institutional right to claim. Nevertheless, on these points the Advisory Opinion undoubtedly fits with the tenor of the governance of the Area generally, and it is unclear how objectionable most members of the international community will consider these findings in light of the particular nature of the Area.

\footnotetext{
${ }^{76}$ Advisory Opinion, paragraph 180. On such obligations generally, see M. Ragazzi, The Concept of International Obligations Erga Omnes (Oxford, Oxford University Press, 1997).

77 Cf. Birnie, et al., supra note 41, 233: "While... obligations of global environmental responsibility may have an erga omnes partes character, in the sense that they are owed to all states acting through collective institutions of treaty supervision, in the 1974 Nuclear Tests Cases the ICJ was unsympathetic to the notion of an actio popularis allowing high seas freedoms to be enforced by any state".

78 Article 48 of the Articles on State Responsibility goes on to set out what a State "other than an injured State" might "claim from the responsible States", namely "(a) cessation of the internationally wrongful act, and assurances and guarantees of non-repetition...; and (b) performance of the obligation of reparation in accordance with the preceding articles, in the interest of the injured State or of the beneficiaries of the obligation breached".

79 C. Redgwell, 'International Environmental Law' in: M. Evans (ed.), International Law (Oxford, Oxford University Press, 2010, 3rd ed.) 697: "the status of [the] provision[...] remains de lege ferenda".

${ }^{80}$ For a general discussion, see J. Peel, 'New State responsibility rules and compliance with multilateral environmental obligations - some case studies of how the new rules might apply in the international environmental context' (2001) 10 Review of European Community and International Environmental Law 82.
} 


\section{The Precautionary Approach}

As noted above, the Chamber found that many of the direct obligations imposed upon sponsoring States, either by virtue of the Convention or the Regulations, were also integral aspects of the general obligation of due diligence. The effect of this on the responsibilities of sponsoring States' obligations should not be underestimated, nor the legal consequences ignored. By incorporating many of these direct obligations into the due diligence obligation, the Chamber was thus able not only to concurrently strengthen both the due diligence and the direct obligations but also simultaneously broaden their remit. In particular, as regards the precautionary approach, by requiring it as an element of due diligence, the Chamber extends its application to all relevant activities in the Area and not just the activities governed by the Regulations. ${ }^{81}$ The legal significance of this should not be lost; an obligation only contained within subsequent secondary regulations has now been transformed into a fundamental element of the conventional requirement on sponsoring States. Through this, the Chamber has refashioned States' general obligations to take into account more recent legal developments. Although this is not the first time a judicial tribunal has sought to give effect to precaution withoutor with limited — explicit textual authorisation, ${ }^{82}$ nevertheless one should not ignore the overall significance of what this change might mean. Sponsoring States will now be required to respect and apply the precautionary approach in all aspects of their activities in the Area. Of course, from an environmental perspective, a broad application of the precautionary approach is a positive development. However, one must equally be aware of the constantly precarious role of the international judiciary in pushing forward the law too quickly.

\footnotetext{
${ }^{81}$ Advisory Opinion, paragraph 131: "the precautionary approach is also an integral part of the general obligation of due diligence of sponsoring States, which is applicable even outside the scope of the Regulations". This article refers to the precautionary approach throughout, rather than the precautionary principle, but as the Advisory Opinion later indicates, the change in wording has little bearing on the issue of its legal status.

82 See, for instance, European Communities: Measures concerning Meat and Meat Products (Hormones) (WT/DS26, WT/DS48; adopted on 13 February 1998) paragraph 124: "the precautionary principle does not, by itself, and without a clear textual directive to that effect, relieve a panel from the duty of applying the normal (i.e. customary international law) principles of treaty interpretation". But note also in the same paragraph: "the precautionary principle indeed finds reflection in ... the [Sanitary and Phytosanitary] Agreement ... [Moreover] a panel charged with determining, for instance, whether "sufficient scientific evidence" exists... may, of course, and should, bear in mind that responsible, representative governments commonly act from perspectives of prudence and precaution where risks of irreversible, e.g. lifeterminating, damage to human health are concerned"; http://wto.org/english/tratop_e/ dispu_e/cases_e/ds26_e.htm (last accessed: August 2011).
} 
Nevertheless, on balance, most commentators will probably view the Chamber's judgment as altogether reasonable in light of the nature of the environment in question, and in particular the way in which the precautionary approach is already embedded within aspects of the regime (with the consent of the States Parties). Thus it would seem logical, regardless of legal formality, to incorporate the precautionary approach within "due diligence".

However, one should not lose sight of the normative 'journey' of the precautionary approach within the context of the Area. The Chamber maps out very succinctly its development from a 'soft law' principle to a binding direct legal obligation, ${ }^{83}$ and indeed on to a nascent rule of customary international law (on which see further below). It is important that the precautionary approach was incorporated within the Nodules and Sulphides Regulations, not by direct transposition but by express reference to the Rio Declaration; the Regulations ${ }^{84}$ note that States and the Authority "shall apply a precautionary approach, as reflected in Principle 15 of the Rio Declaration". ${ }^{85}$ Moreover, the Chamber anticipates that the reference to the precautionary approach in the Regulations, which govern prospecting and exploration, will be repeated or indeed "further develop[ed]" by the Authority "when it regulates exploitation activities and activities concerning other types of minerals" ${ }^{86}$ Equally, the Chamber notes that the standard clauses for exploration in the Sulphides Regulations, which contractors sign, also contain reference to precaution. However, the Chamber does not pick up (or chooses not to do so) that the relevant standard clause states that precaution is to apply "as far as reasonably possible", which is an important qualification and would seem to distinguish between the imposition of the precautionary approach on sponsoring States and its application to contractors.

It is highly unusual - if not unique-for a judicial body to be given the opportunity to interpret the Rio Declaration. Other international courts and tribunals have reflected on 'soft law' declarations and principles, ${ }^{87}$ but rarely

${ }^{83}$ Advisory Opinion, paragraph 127: "The provisions of the... Regulations transform this non-binding statement of the precautionary approach in the Rio Declaration into a binding obligation”.

${ }^{84}$ Namely Regulation 31(2) Nodules Regulations and Regulation 33(2) Sulphides Regulations.

85 Principle 15 Rio Declaration: "In order to protect the environment, the precautionary approach shall be widely applied by States according to their capabilities. Where there are threats of serious or irreversible damage, lack of full scientific certainty shall not be used as a reason for postponing cost-effective measures to prevent environmental degradation".

${ }^{86}$ Advisory Opinion, paragraph 130.

87 As the ICJ noted in Case concerning Gabčikovo-Nagymaros Project (Hungary/Slovakia), ICJ Reports (1997) 7, 78: "new norms and standards have been developed, set forth in a great number of instruments during the last two decades". More explicitly, the WTO Appellate 
has a tribunal been able to give it legal effect in quite the same manner. Thus, its interpretation of the precautionary approach should be at least noted, if not given special weight. The remainder of this section therefore focuses on two other aspects of the precautionary approach: first, its legal status and second, its content. Finally, the section briefly mentions the Chamber's endorsement of best environmental practices, which it sees as very much supplementary to the precautionary approach.

\section{Legal Status}

The precautionary approach has proved to be an especially controversial aspect of international environmental law. ${ }^{88}$ Different courts and tribunals have struggled to give it substantive effect and to determine its legal status, including panels and the Appellate Body of the World Trade Organization (WTO), the ICJ (ICJ) and the ITLOS. ${ }^{89}$ Moreover, while individual judges have varied in their tone from positive endorsement ${ }^{90}$ to circumspection, ${ }^{91}$ the tribunals themselves have largely eschewed answering the question about its legal status and focused upon less contentious aspects of the approach, notably synergies with established law. The Advisory Opinion should thus be seen as significant, as arguably making the clearest statement yet about the legal status of the precautionary approach. The Chamber is of the view that the continual reliance on the precautionary approach in international treaties (as well as such other instruments as the Nodules and Sulphides Regulations themselves) "has initiated a trend towards making this approach part of customary

Body in United States: Import Prohibition of Certain Shrimp and Shrimp products ('ShrimpTurtle I') (WT/DS58/AB/R, adopted on 6 November 1998) references the 1992 Rio Declaration and Agenda 21 on several occasions.

${ }^{88}$ For analysis, especially from a maritime context, see M. Fitzmaurice, Contemporary Issues in International Environmental Law (Cheltenham, Edward Elgar, 2009) chapter 1.

89 Ibid., at 4: "the practice of international courts and tribunals regarding the precautionary principle is mostly focused on the lengthy (and often not very illuminating) discussions whether or not it has already acquired the status of customary law or general principles of law".

90 Case Concerning Pulp Mills (Request for the Indication of Provisional Measures) (13 July 2006), ICJ Reports (2006) 113, 152, dissenting opinion of ad hoc Judge Vinuesa: "the precautionary principle is not an abstraction or an academic component of desirable soft law, but a rule of law within general international law as it stands today".

${ }^{91}$ Mox Plant (Ireland v. United Kingdom) (Order of 3 December 2001), separate opinion of Judge Wolfrum: "It is still a matter of discussion whether the precautionary principle or the precautionary approach in international environmental law has become part of international customary law"; http:/www.itlos.org/fileadmin/itlos/documents/cases/case_no_10/sep.op .Wolfrum.E.orig.pdf (last accessed: August 2011). 
international law". ${ }^{92}$ Though still somewhat tentative and certainly not a declaratory statement of the law, it goes further than most tribunals have yet braved. As with the WTO Appellate Body, perhaps it is the specialist nature of the Chamber that prevented it from making a more definitive ruling. Moreover, this finding of an (admittedly inchoate) rule of custom was not through detailed examination of State practice and opinio juris but through the general summation of trends, which is a somewhat unfortunate, if necessary, characteristic of general judicial findings of custom. This is not a criticism per se, but recognition of the rather incremental, sometimes sporadic, evolution of international law, especially in the field of international environmental law. ${ }^{93}$

It is interesting that the Chamber does not come to this view without support; as with the customary status of EIA, the Chamber relies upon the ICJ's decision in Pulp Mills to substantiate its position. It quotes the ICJ when it states that "a precautionary approach may be relevant in the interpretation and application of the provisions of the" relevant treaty. ${ }^{94}$ For the Chamber, this can reasonably be interpreted as meaning that the precautionary approach is a rule of custom, or more specifically, a "relevant rule[...] of international law" for the purposes of Article 31(3)(c) of the 1969 Vienna Convention on the Law of Treaties. ${ }^{95}$ Whereas others have sought to argue that the judicial use of notions, such as the precautionary approach, can be justified by viewing them as an interstitial norm or as a 'soft law' general principle, ${ }^{96}$ the Chamber relies on a perhaps more traditional interpretation as to what the ICJ was seeking to achieve in its judgment. Though ultimately this may prove to be the more radical interpretation, and undoubtedly it progresses the rather more nuanced comment made by the ICJ. Nevertheless, the Chamber ultimately leaves the final promulgation of the customary status to another day, or at least to another judicial tribunal.

${ }_{92}$ Advisory Opinion, paragraph 135.

${ }_{93}$ Fitzmaurice, supra note 88, 4: "We should also be aware of the phenomenon... of the existence of a divergence between the traditional theory of international law based on consistent and uniform State practice and the norms 'generally espoused as customary', which defy classical tests of international customary law” quoting D. Bodansky, 'Customary (and Not So Customary) International Environmental Law' (1995) 3 Indiana Journal of Global Legal Studies 105.

94 Pulp Mills, paragraph 164.

95 Article 31(3)(c): "There shall be taken into account, together with the context:...(c) any relevant rules of international law applicable in the relations between the parties".

96 See A. Boyle, 'Soft Law in International Law-Making' in Evans (ed.), supra note 79, 133: "If, alternatively, the precautionary principle is viewed as a general principle of law, on which decision-makers and courts may rely when deciding cases and interpreting treaties, then its subsequent use by national and international courts, and by international organizations, is easier to explain". 


\section{Threshold of Risk}

As to the matter of what the Chamber understands precaution to require, in many ways this is a much more interesting discussion. As noted above, the Regulations do not provide their own interpretation, but refer explicitly to the Rio Declaration. As the Chamber makes clear, Principle 15 is structured in two parts-a first sentence, which "seems to refer in general terms" and a second sentence, which "limits its scope", ${ }^{97}$ referring here to the qualifications of "serious and irreversible", "cost-effective" and even "environmental degradation" (presumably in contrast to other forms of harm, including economic). Moreover, as discussed later, the Chamber also discusses the notion of "capabilities" as found in that text. The express reference to, and seeming affirmation, of the wording of Principle 15 by the Chamber is thus not surprising in light of how it is introduced into the Regulations. What becomes rather more curious is the later interpretation of the precautionary approach in the context of the due diligence obligation. The Chamber makes the following statement:

This obligation [namely, of due diligence] applies in situations where scientific evidence concerning the scope and potential negative impact of the activity in question is insufficient but where there are plausible indications of potential risks. A sponsoring State would not meet its obligations of due diligence if it disregarded those risks. ${ }^{98}$

The Chamber's language here is notable. There is no reference to "threats of serious or irreversible damage", rather it talks of "plausible indications of potential risks". Is this a dilution of the requirements of Principle 15? It certainly reads as such. The notion of "plausible indications" is a significantly lower threshold than most - if virtually all —other interpretations of the precautionary approach, other than perhaps those rare instances which have reversed the burden of proof. ${ }^{99}$ Did the Chamber intend to vary the precautionary approach in this way? There is certainly no textual justification in the

${ }_{97}$ Advisory Opinion, paragraph 128.

98 Ibid., paragraph 131. Emphasis added.

99 See, for instance, 1996 Protocol to the 1972 (London) Convention on the Prevention of Marine Pollution by Dumping of Wastes and Other Matter (36 ILM (1997) 7), Article 3(1): "In implementing this Protocol, Contracting Parties shall apply a precautionary approach to environmental protection from dumping of wastes or other matter whereby appropriate preventative measures are taken when there is reason to believe that wastes or other matter introduced into the marine environment are likely to cause harm even when there is no conclusive evidence to prove a causal relation between inputs and their effects". 
Regulations or judicial reasoning in the Advisory Opinion that would support a fundamental revision of the wording of Principle 15. It might be argued that the Chamber was making a distinction between how the precautionary approach applies within the context of the due diligence obligation as compared to the precautionary approach as an autonomous obligation. In terms of how the Advisory Opinion is structured, this might make some sense. Later on, when discussing how the discrete requirement of "best environmental practices" becomes part of the due diligence obligation, the Chamber does say it does so only in "general terms", thus it might be argued that the Chamber is making a similar distinction here. The argument is namely that the precautionary approach loses some of its prescriptiveness and legal rigour when applied within the more general context of the due diligence obligation. Certainly, the Chamber goes on to quote ITLOS's 1999 Order in the Southern Bluefin Tuna cases, where the precautionary approach is translated into the more amorphous requirement of "prudence and caution" ${ }^{100}$ But can such an argument stand up to scrutiny? Does the precautionary approach—as an autonomous obligation-occupy a discrete sphere of influence which would permit such a demarcation from its application within the due diligence context? The precautionary approach is best viewed as a horizontal obligation that exists alongside other commitments, and whilst it makes sense that even where the stringent conditions for the application of the precautionary approach are not met, environmental prerogatives still demand the highest level of environmental protection feasible (what ITLOS was seeking to achieve by referring to "prudence and caution"), the Chamber does not seem to be referring here to such a 'sub-optimal' use of the precautionary approach. Indeed, the Chamber very clearly says: "the precautionary approach is also an integral part of the general obligation of due diligence", and thus in no way seems to be seeking to demarcate a different, or lower, 'form' of precaution.

An alternative understanding might be that the overall application of the precautionary approach within the Area as a particularly sensitive environment $^{101}$ — either as an autonomous obligation or as part of due diligence-

100 Order of 27 August 1999 (Southern Bluefin Tuna Cases (New Zealand v Japan; Australia v Japan)) paragraph 77; http://www.itlos.org/fileadmin/itlos/documents/cases/case_no_3_4/ Order.27.08.99.E.pdf (last accessed: August 2011)). Cf. Fitzmaurice, supra note 88, 66, who sees a "trend in environmental management which is characterized by a more practical approach... adopting more humble but at the same time more realistic goals... Therefore, 'prudence and caution' are recommended".

101 The scale of the environmental impact of exploring and exploiting mineral resources on the Area remains unclear. As the then Secretary-General of the Authority, Satya Nandan, said in a preface to a 1999 report on a 1998 workshop organised by the Authority on the development of environmental guidelines: "While it is recognized that there is little or no impact in the 
demands a more stringent interpretation and consequent lower threshold of risk. The Chamber noted that the obligation of due diligence varies in the light of the sensitivity of the environment in which States must act, or are required to regulate for. Thus, similarly, it might be argued that the precautionary approach must vary in light of the environmental context, with the consequence that the Area demands a particularly low threshold before risk is assessed and managed. But if this were true, why do the Regulations simply refer to Principle 15 and not expand upon this in much greater detail? Moreover, the standard contractual clause in the Sulphides Regulation refers to the fact that the precautionary approach is to be applied "as far as reasonably possible" by a contractor. ${ }^{102}$ This is not a strong version of the precautionary approach in general and certainly not if one were to seek to apply an even more stringent version of the precautionary approach. It is thus difficult to argue that the Chamber intended to impose a more stringent duty of precaution on sponsoring States in the Area.

Nevertheless, unless one is to consider these words to be without legal significance, one should not discount them entirely. At best, they are an unfortunate attempt to say the same thing in a different way; at worst, they confuse the debate. In particular, it dilutes the Chamber's finding of customary status for the precautionary approach-for it inevitably raises the matter as to what is being found to be a rule of custom. The Chamber risks being accused of inconsistent judicial activism, which would be unfortunate in light of the overall strengths of the Advisory Opinion. Of course, if the Chamber did

early stages of polymetallic nodule exploration, it is nevertheless possible to begin at an early stage to collect basic environmental information (baseline data) to confirm this hypothesis, and to provide more precise information on possible impacts, as progress is made during the test mining phase of an exploration plan"; http://www.isa.org.jm/files/documents/EN/ Pubs/1998Proceedings.pdf (last accessed: July 2011). See the Note of 26 August 2010 from the Authority's Legal Counsel to the Chamber on the likely impact of exploration and mining activities for nodules on the marine environment, relying on work from the Authority's 2001 Harmonisation Workshop on the Standardization of Environmental Data and Information: Development and Guidelines; http://www.itlos.org/fileadmin/itlos/documents/cases/case_ no_17/ISA_1.pdf (last accessed: July 2011). See also the Submission by Greenpeace and the World Wide Fund for Nature (13 August 2010); http://www.itlos.org/fileadmin/itlos/ documents/cases/case_no_17/Statement_Greenpeace_WWF.pdf (last accessed: July 2011): "Exploitation of the resources of the deep seabed is a high-risk activity because of the difficulty of working at great depths and because so much remains unknown about this region. The deep seabed harbors unusual and diverse ecosystems which are of great interest to science, and whose genetic resources may have medical or other applications. Hydrothermal vents, which are seen as likely areas for mining, play host to a particularly rich diversity of species, with a high degree of endemism".

102 Advisory Opinion, paragraph 133. 
indeed intend for these words of "plausible indications of potential risks" to have normative impact, then - as with any judicial decision-its significance lies not in the mere pronouncement by a judicial body but by the persuasiveness of its reasoning. Without such reasoning, the Chamber has merely added an unfortunate layer to what is a generally positive contribution to the wider debate.

\section{Best Environmental Practices}

Finally, it is worth noting that the Chamber views the obligation of applying "best environmental practices" as synergistic with the precautionary approach, although the Chamber equally recognises that it is also "in general terms" an element of the broader due diligence obligation, and thus like the precautionary approach is applicable across the broad scope of activities within the Area. It is significant that the Chamber comes to this view despite the fact that, unlike the precautionary approach which is featured in both the Nodules and Sulphides Regulations, the obligation of applying/requiring best environmental practices only appears in the later Sulphides Regulations. Nevertheless, "[ $t]$ he adoption of higher standards in the more recent Sulphides Regulations would seem to indicate that in the light of the advancement in scientific knowledge, member States of the Authority have become convinced of the need for sponsoring States to apply "best environmental practices" in general terms". ${ }^{103}$ More specifically, the Chamber goes on to say that because of this, and absent any textual reason that may be found, "it may be found that the Nodules Regulations should be interpreted in light of the development of the law, as evidenced by the subsequent adoption of the Sulphides Regulations". ${ }^{104}$ As with the transfer of the precautionary approach from the Regulations to

103 Advisory Opinion, paragraph 136. As an element of due diligence, this would seem to indicate that best environmental practices are required under customary international law as part of a State's responsibility to weigh up various factors in assessing how to regulate activities that may cause transboundary and global harm. As with precaution, what the ICJ implies in Pulp Mills ("rules and measures adopted by the parties both have to conform to applicable international agreements and to take account of internationally agreed technical standards" (paragraph 197)) is made more explicit in the Advisory Opinion. However, in Pulp Mills, a close reading of the judgment on the matter of how far the parties must keep up with changing international standards fails to reveal whether the obligation in that case flows from the customary obligation of due diligence or the treaty requirement that "measures must be in accordance with applicable international agreements' and 'in keeping, where relevant, with the guidelines and recommendations of international technical bodies" (ibid.). Although a strong case can be made for the former interpretation, textually it would seem to be the latter interpretation which is more defensible.

${ }_{104}$ Advisory Opinion, paragraph 137. 
the overall regime, the Chamber also finds the inclusion of best environmental practices within the later Sulphides Regulations as being sufficient not only to justify its inclusion within the due diligence obligation but also as an interpretative guide to the earlier Nodules Regulations. Similarly, the Chamber finds that the absence of the precautionary approach in the standard clauses in the Nodules Regulations (but its existence in the Sulphides Regulations) is sufficient to require "the sponsoring State to take measures within the framework of its own legal system in order to oblige sponsored entities to adopt such an approach". ${ }^{105}$ The intention of the Parties at the time of the negotiation of the earlier instruments is now giving way to, or being subsumed within, a more evolutionary interpretation, ${ }^{106}$ despite the fact that these instruments are only a single decade (in the case of the two sets of Regulations) apart. ${ }^{107}$ As should be gleaned from the general tone of this article, the judgment is warmly received by this author, but nevertheless, even he wishes to stop and reflect on some of these arguably more creative-radical seems too strong-aspects of treaty and instrument interpretation, which are utilised by the Chamber to ensure maximum coherence and contemporaneity in its application and reach.

\section{Common but Differentiated Responsibilities}

It was Nauru's concerns as a developing State that initially prompted the call for an advisory opinion. The prospect of it being financial liable for damage caused by an entity that it sponsors raised the spectre for Nauru of "losing more than it actually has". Though this seems slightly exaggerated, there is nevertheless truth in the argument, because of the sensitivity of the environment of the Area, as well as the surrounding high seas, and the consequent level of damage that could be done as a result. Thus, by raising issues as to when responsibility may arise and what the level of any liability might be, Nauru's questions are of general importance. In asking these questions, Nauru

\footnotetext{
105 Advisory Opinion, paragraph 134.

106 See Iron Rhine Railway, paragraph 80: "it seems that an evolutive interpretation, which would ensure an application of the treaty that would be effective in terms of its object and purpose, will be preferred to a strict application of the intertemporal rule". However, note Judge Bedjaoui in his separate opinion in Gabčikovo-Nagymaros, ICJ Reports (1997) 7, 122: "the essential basis for the interpretation of a treaty remains the 'fixed reference' to contemporary international law at the time of its conclusion. The 'mobile reference' to the law which will subsequently have developed can be recommended only in exceptional cases".

107 Indeed, the Advisory Opinion may provide a certain impetus for the States Parties to review the Nodules Regulations in light of more recent developments.
} 
was hoping, of course, for a legal view that the obligations of developing States were measurably different from those of developed States.

The Chamber was thus faced with the complex question of how far developing States that sponsored entities were subject to preferential rules. On first appearances, the question would appear to be highly nuanced, as the regime contains numerous provisions which do take into account the interests of developing States. In particular, the LOSC states that "[t] he effective participation of developing States in activities in the Area shall be promoted... having due regard to their special interests and needs", ${ }^{108}$ going on to reference specifically land-locked and geographically disadvantaged developing States. The Chamber thus rightly acknowledges those provisions of the Convention (as affected by the 1994 Implementation Agreement) that do take such considerations into account. Nevertheless, the Chamber focuses on the specific wording of Article 148 which states that such effective participation "shall be promoted as specifically provided for in this Part", ${ }^{109}$ thus demarcating those provisions for which no specific mention is made in terms of the level of development. As the Chamber remarks, "there is no general clause for the consideration of such interests and needs beyond what is provided for". ${ }^{110}$ Moreover, there is no discussion of common but differentiated responsibilities, either as an element of global environmental policy, never mind as an emerging autonomous legal principle. This would seem to reflect the general perception as to the inherently political nature of Principle 7 of the Rio Declaration, which endorsed the notion of common but differentiated responsibilities; ${ }^{111}$ while the principle has found reflection in treaty law, it remains notably absent from judicial discussion, ${ }^{112}$ notwithstanding the endorsement and utility of sustainable development as a motif more generally by courts and tribunals.

\footnotetext{
108 Article 148 LOSC.

109 Emphasis added.

110 Advisory Opinion, paragraph 156.

111 Principle 7 Rio Declaration: "States shall cooperate in a spirit of global partnership to conserve, protect and restore the health and integrity of the Earth's ecosystem. In view of the different contributions to global environmental degradation, States have common but differentiated responsibilities. The developed countries acknowledge the responsibility that they bear in the international pursuit to sustainable development in view of the pressures their societies place on the global environment and of the technologies and financial resources they command". For comment, see Y. Matsui, "The Principle of "Common but Differentiated Responsibilities'” in: N. Schrijver and F. Weiss (eds.), International Law and Sustainable Development: Principles and Practice (Leiden/Boston, Martinus Nijhoff, 2004) 73-96.

112 This is not to dispute that the principle of common but differentiated responsibilities, as well as reference to the special needs and interests of developing countries (Principle 6 Rio Declaration), has had significant impact on the development of multilateral treaty regimes, both at their initial adoption and subsequently as they are further refined and implemented.
} 


\section{Uniformity of Standards}

Nevertheless, the Chamber felt required to identify not just the limits of preferential treatment within the regime, but also why differentiation beyond this - in the case of sponsoring developing States-would be inappropriate. Though dressed in legal language, the Chamber's position on this is equally determined by considerations of policy in seeking to establish clear parameters for a regime in many ways at the beginning of its operational existence. Notably, the language of the high seas-and some of the difficulties that have faced that particular maritime zone-are picked and used as a counterpoint to indicate a level of legality and order that some feel is often missing on the high seas.

Equality of treatment between developing and developed sponsoring States is consistent with the need to prevent commercial enterprises based in developed States from setting up companies in developing States, acquiring their nationality and obtaining their sponsorship in the hope of being subjected to less burdensome regulations and controls. The spread of sponsoring States 'of convenience' would jeopardize uniform application of the highest standards of protection of the marine environment, the safe development of activities in the Area and protection of the common heritage of mankind. ${ }^{113}$

Whether the difficulties of regulating ships flying flags of convenience on the high seas is directly analogous to sponsored entities seeking out States 'of convenience' is disputable - though the point that differentiation in standards would undermine overall regulatory uniformity must nevertheless be accurate.

However, the Chamber recognises that differentiation may be possible if enacted within the Authority's express rules imposed upon sponsoring States ${ }^{114}$ and gives the example of the incorporation of the precautionary approach (Principle 15 Rio Declaration) in the Nodules and Sulphides Regulations. Relying on the wording of Principle 15 which speaks of States applying a precautionary approach "according to their capabilities", the Chamber notes

\footnotetext{
However, many consider the principle to be inherently political in nature and thus beyond the purview of judicial decision-making. As a 'soft law' principle, subject to variable political claims, it has so far proved difficult to strengthen the normative quality of the principle. Nevertheless, even where it has been found advisable for reasons of environmental protection not to support increased differentiation in terms of commitments, it is arguable that judicial bodies should always seek to at least acknowledge the broader reality of socio-economic differences between States - the Advisory Opinion arguably does do this, on which see below.

113 Advisory Opinion, paragraph 159.

${ }^{114}$ Ibid., paragraph 160.
} 
that it "follows that the requirements for complying with the obligation to apply the precautionary approach may be stricter for the developed than for the developing sponsoring States". ${ }^{115}$ But the Chamber is clearly concerned not to leave the door too far ajar, noting immediately afterwards that the requirement to use best environmental practices in the Sulphides Regulations is equally not so qualified.

Moreover, and perhaps of greater interest, is the Chamber's determination not to categorise developed and developing States too sharply. Not all within the same "group" should be considered in the same light; so as regards the precautionary approach, "the reference to "capabilities" is only a broad and imprecise reference to the differences in developed and developing States". ${ }^{116}$ The Chamber goes on to add: "What counts in a specific situation is the level of scientific knowledge and technical capability available to a given State in the relevant scientific and technical fields" ${ }^{117}$ This is a wonderfully conceived sentence. It reads as liberation for individual States; each is assessed against its own level of development at any particular time. It is refreshingly individualistic against the usual backdrop of over-generalisation sometimes to be found in international environmental law. But the constraint for States is equally obvious; individual States can no longer hide behind generalities and assumptions; being a developing State is itself not enough to justify a particular stance. Of course, in reality, what the Chamber proposes here is very difficult to implement and operationalise, not only in everyday situations but also by judicial tribunals called to make an assessment. Moreover, the Chamber's comments are not restricted here to activities in the Area, and thus it has general resonance for the application and use of the precautionary approach, and has the potential to be used in the future to set a higher level of scrutiny before a developing State is able to say that its level of development prevented it from acting in anticipation of scientific certainty.

Curiously, in this discussion on capabilities and differentiation, there is no mention of how due diligence must invariably be affected by a State's level of development. Indeed, the Chamber would seem to be somewhat reticent on this point, after highlighting that there was no such qualification as regards the use of best environmental practices, which is viewed as part of the due diligence requirement. Moreover, in the Chamber's earlier discussion of due diligence, although there is a mention of how the content of this obligation may change in light of a range of factors, these factors do not include a country's capacity to implement and enforce such rules in light of its level of

115 Advisory Opinion, paragraph 161.

116 Ibid., paragraph 162.

117 Ibid. 
development. This would suggest—-both explicitly by what it says about best environmental practices and implicitly by what it does not say about due diligence- that the Chamber does not consider development level to be a relevant consideration. This is in contrast not only to what it says itself about the precautionary approach but also to the commentary to the ILC 2001 Articles on Transboundary Harm which does very clearly state that " $[\mathrm{t}]$ he economic level of States is one of the factors to be taken into account in determining whether a State has complied with its obligation of due diligence. But a State's economic level cannot be used to dispense the State from its obligation". ${ }^{118}$ This would seem to be a much more balanced approach than to ignore the issue altogether as the Chamber seems to have done.

\section{Liability and Responsibility}

Although the Chamber was not prepared to endorse a liberal approach to preferential treatment for developing States, it does at another point of the Advisory Opinion go some way to assuaging the initial concern of Naura as a developing State and, at the same time, raise interesting issues of general international law as regards the potential extent of a sponsoring State's liability. It is important that the Chamber rightly distinguishes between the contractor's liability and the sponsoring State's liability. Historically, as both flow from the same damage, there may be some confusion not only as to when each is liable, and for what, but also the relationship between these liabilities. The responsibility of the State to make reparation is a matter of international law whereas the liability of a private entity is an issue of domestic law, as affected by necessary conflict of laws or harmonisation rules. ${ }^{119}$ This distinction between State and private liability is not necessarily altogether different in relation to the Area, though the link between the 'domestic' and the 'international' is more closely inter-related by means of the contract that any sponsored entity signs with the Authority and the legal requirement that a sponsoring State must ensure respect for such commitments in its domestic law. Thus, the Chamber is perhaps more appropriately situated than many international tribunals to comment upon the relationship between these liabilities. Arguably, because of this, the Chamber makes a number of points, both of particular and indeed arguably of wider relevance.

1182001 Articles on Transboundary Harm, commentary to Article 3 (ILC, supra note 45, 155).

119 See A. Boyle, (2005) 'Globalising Environmental Liability: the Interplay of National and International Law’ 17 Journal of Environmental Law 3. 
First, a sponsoring State's liability arises from a breach of its own responsibilities of due diligence (or of a direct obligation), and not from a breach of the contractor's. As Freestone notes, this will disappoint those who were wishing the Chamber would find a system of strict liability but the wording of the Convention was itself against this. ${ }^{120}$ Second, the Chamber recognises that the contractor's liability is for the "actual amount of the damage", ${ }^{121}$ although the form reparation would take "will depend on both the actual damage and the technical feasibility of restoring the situation". ${ }^{122}$ Third, and importantly for developing States such as Nauru:

the liability of the sponsoring State depends upon the damage resulting from the activities or omissions of the sponsored contractor. But... this is merely a trigger mechanism. Such damage is not, however, automatically attributable to the sponsoring State. ${ }^{123}$

In other words, whilst the damage that occurs may give rise to liability for both contractor and State, this will not immediately result in liability for the sponsoring State. This is a fundamental finding by the Chamber and pivotal to the Advisory Opinion. First, if the contractor (which causes the damage) compensates to the full amount required "there is no room for reparation" by the State. ${ }^{124}$ Second, and significantly - and perhaps less certain in terms of what the Chamber would say on this point-was whether residual liability rested with the State where either the contractor was not able to pay to the full extent (but where the State had met its due diligence obligations) or where the sponsoring State had breached its due diligence commitments but that this could not be causally linked to the damage. As the Chamber notes, different parties before it took diametrically opposite positions on this question.

However, the Chamber was very certain, and arguably it is one of the clearest passages in the Advisory Opinion. It notes that whilst contractor and State liabilities exist "in parallel", there is no scope for residual liability. Based on a very classical understanding of the nature of the due diligence obligation, the Chamber remarks: " $t$ ] he liability of the sponsoring State arises from its own failure to comply with its responsibilities under the Convention and related instruments". ${ }^{125}$ Therefore, whilst "the liability of the sponsoring State depends

120 Freestone, supra note 2.

121 LOSC Annex III, Article 22.

122 Advisory Opinion, paragraph 197.

123 Ibid., paragraph 201.

124 Ibid., paragraph 202.

125 Ibid., paragraph 204. 
on the occurrence of damage resulting from the failure of the sponsored contractor... this does not make the sponsoring State responsible for the damage caused". ${ }^{126}$ If on the other hand, the State has breached its due diligence obligations and there is a causal link to the damage (and the contractor itself cannot or does not compensate), the requirement to make full reparation for the "actual amount of the damage" is the same on the State as it is on the sponsored contractor.

Recognising that by not imposing a regime of residual liability, it opens up the possibility for instances of uncompensated damage, the Chamber refers back to the text of the Convention and suggests that the Authority may wish to consider whether to establish a "trust fund to compensate for the damage not covered". ${ }^{127}$ This seems particularly important as the Chamber takes note of the failed efforts on the part of the International Law Commission to address the issue of compensation for damage resulting from acts not prohibited under international law. ${ }^{128}$ Thus, without clearer guidelines in international law on "State liability for lawful acts", ${ }^{129}$ the Chamber is left to both remind the Authority of the potential desirability of a trust fund and, more specifically, that LOSC Article 304 allows for further development of rules of international law in relation to responsibility and liability.

In conclusion, on the issue of developing States and the Area, might it be considered that what the Chamber takes with one hand (namely, that preferential treatment is limited to that expressly provided for), it gives with another (namely, the Chamber's comments on liability)? Perhaps. Certainly the Chamber's decision that there is no scope for residual liability will be welcomed by potential sponsoring States, ${ }^{130}$ and not just developing countries. Moreover, though the analogy is somewhat strained, the possibility of the emergence of States of convenience cannot be discounted. Thus, the common heritage status of the Area both provides expression to, but also a justification for constraining, the interests_-real or perceived—of developing State Parties. As to whether more could have been made of the notion of common

\footnotetext{
126 Ibid.

127 Advisory Opinion, paragraph 205. The Chamber was referring to Article 235(3) LOSC, which states that "where appropriate, development of criteria and procedures for payment of adequate compensation, such as compulsory insurance or compensation funds".

${ }^{128}$ For general analysis, see A. Boyle, 'State Responsibility and International Liability for Injurious Consequences Not Prohibited by International Law: A Necessary Distinction' (1990) 39 International and Comparative Law Quarterly 1.

${ }^{129}$ Advisory Opinion, paragraph 209.

${ }^{130}$ Indeed, this is arguably shown by the resubmission of the applications to the Authority by Nauru and Tonga (see note 10).
} 
but differentiated responsibilities in this context, the Chamber was arguably right not to stray beyond the text of the LOSC to find a general justification for differentiation, as this would be a Pandora's box and create as many problems as it would appear to solve. If there is criticism of the Advisory Opinion here, it is the unanswered question about due diligence-as a question of fact, dependent on a range of variables, should not the level of development be one of them? If the Chamber is of the view that it should not, it has unfortunately created a paradox through how it understood the contextual nature of the application of the precautionary approach in this situation.

\section{The Principle of Good Governance}

The final matter to consider is what the Chamber believed sponsoring States are required to accomplish domestically to meet their international obligations in terms of their due diligence obligation. If somewhat artificially, though not completely without reason, these final issues are grouped around the principle of good governance. ${ }^{131}$ The first point to make is that the Chamber sought to address whether a sponsoring State could achieve its obligation to regulate sponsored contractors purely through the means of private law and contractual relations. While there may be aspects of a sponsored entity's behaviour that could be governed by administrative measures or even contract, the Chamber was equally clear that there were numerous other aspects of its obligations that could not. As the Chamber notes, Article 4, paragraph 4 of LOSC Annex III specifies quite clearly the obligation to adopt binding laws and regulations in this instance. Indeed, the Chamber is of the view that to do otherwise would be incompatible with the Convention "in general"- -which might be taken to refer to the object and purpose of the LOSC-and the governance of the Area, in particular. This is perhaps not too surprising, or unexpected. An international convention premised on the rule of law in marine affairs might easily be read as preferring (though not always requiring) States to implement their obligations through legally binding norms.

\footnotetext{
${ }^{131}$ New Delhi Declaration, paragraph 6.1: "The principle of good governance is essential to the progressive development and codification of international law relating to sustainable development. It commits States and international organizations: (a) to adopt democratic and transparent decision-making procedures and financial accountability;... (c) to respect the principle of due process in their procedures and to observe the rule of law".
} 


\section{Scepticism of "Contractual Approach" to Regulation}

The Chamber could have limited its discussion on this matter to positive law. What is perhaps more surprising is where the Chamber goes next with its Advisory Opinion, first noting the good governance justifications for the enactment of law, over and above mere contracts, and then outlining (within the confines of its judicial role) some of the general principles that should guide the content of the law and regulations. Thus, the Chamber manages to preserve its judicial independence whilst setting outer parameters for what it considered to be acceptable. Reading the Advisory Opinion as a whole, it might be concluded this is the only part of the judgment which strays far into general obiter, though the remarks made-as will be seen-are nevertheless sensible for all that.

In terms of the first issue, - that of compliance through contract-the Chamber relies heavily on the need for accountability and public availability of relevant documents. As it says, "[ $\mathrm{t}]$ he 'contract approach' would, moreover, lack transparency. It will be difficult to verify, through publicly available measures, that the sponsoring State had met its obligations" ${ }^{132}$ In particular, recognising that neither the Convention nor either set of Regulations require sponsorship agreements between State and sponsored entity to be submitted either to the Authority or released publicly (if indeed such an agreement has been made), the Chamber is clearly anxious to avoid the capacity of either party to escape their obligations. Moreover, though such a lack of information is inevitably based on commercial confidentiality, the Chamber is equally convinced as to the sponsoring State's particular obligation for the good governance of the Area-the Chamber noting again the commitment in LOSC Article 153 that the sponsoring State is under a direct obligation to assist the Authority. Moreover, the Chamber makes clear that in relation to the other principal private transaction-the exploration contract between the sponsored entity and the Authority, to which the sponsoring State is not a partythe sponsoring State is equally under an obligation to adopt binding rules that not only do not hinder the fulfilment of the contract but "rather assist the contractor in that respect". ${ }^{133}$

\section{Hallmarks of Regulation: Reasonableness and Non-Arbitrariness}

On the question of the content of such binding rules, the Chamber also gives some direction to sponsoring States as to the content of the measures

132 Advisory Opinion, paragraph 225.

133 Ibid., paragraph 238. 
which would "enable it to discharge its responsibilities". ${ }^{134}$ The Chamber is keen to stress it will not interfere in legitimate areas of State discretion; "[p] olicy choices on such matters must be made by the sponsoring State" - to do otherwise would run the risk of the Chamber as a "[j]udicial bod[y] [to] perform functions that are not in keeping with... [its] judicial character" ${ }^{135}$ However, this does not prevent the Chamber from making comments of certain "general considerations that a sponsoring State may find useful". ${ }^{136}$ The term "useful" here is interesting; purposely not prescriptive, nevertheless it is not as anodyne as a literal first reading might suggest. Indeed, though the Chamber recognises that measures will vary between sponsoring States, often dependent on the nature of the "framework of its legal system", State discretion is not absolute. Above all, such measures must be "reasonably appropriate". ${ }^{137}$ The Chamber's comments on this issue may be divided into four. First, it gives specific examples of the type of rules that a sponsoring State may wish to include. ${ }^{138}$ Second, it refers to examples of existing domestic law as evidence of good practice. ${ }^{139}$ Third, it acknowledges that domestic law is permitted to require higher environmental standards than the "minimum standard of stringency" imposed by the Convention and Regulations. ${ }^{140}$ Finally, fourth — though for completeness, it should be pointed out that the Chamber places this first-it sets out what it terms "some general considerations", which are worth quoting in full.

\footnotetext{
${ }^{134}$ Advisory Opinion, paragraph 227.

135 Ibid.

136 Ibid.

137 Annex III, Article 4, paragraph 4 LOSC: "A sponsoring State shall not, however, be liable for damage caused by any failure of a contractor sponsored by it to comply with its obligations if that State Party has adopted laws and regulations and taken administrative measures which are, within the framework of its legal system, reasonably appropriate for securing compliance by persons under its jurisdiction".

138 Advisory Opinion, paragraph 234: "These provisions may concern, inter alia, financial viability and technical capacity of sponsored contractors, conditions for issuing a certificate of sponsorship and penalties for non-compliance by such contractors".

139 Namely, "the Deep Seabed Mining Law adopted by Germany and of similar legislation adopted by the Czech Republic" (Advisory Opinion, paragraph 237). Press Release (14 July 2011): Seabed Council discusses Recent Advisory Opinion (http://www.isa.org.jm/files/documents/EN/Press/Press11/SB-17-5.pdf (last accessed: July 2011)): "Several delegations, including Australia, Bangladesh and Brazil supported Mexico's call for "model laws" to be developed by the Authority... [The representative from Germany] said that his country would be using the advisory opinion as a starting point for a review of its legislation relating to the provision of recourse and compensation arising from seabed activities. The Netherlands representative suggested that in developing model legislation, the Authority could seek guidance from States Parties which already had such legislation in place".
}

${ }^{140}$ Advisory Opinion, paragraph 240. 
...the sponsoring State must take into account, objectively, the relevant options in a manner that is reasonable, relevant and conducive to the benefit of mankind as a whole. It must act in good faith, especially when its action is likely to affect prejudicially the interests of mankind as a whole... Reasonableness and nonarbitrariness must remain the hallmarks of any action taken by the sponsoring State. ${ }^{141}$

This seems very sensible in tone, if slightly abstract in nature. Undoubtedly, the special nature of the Area as common heritage of mankind has significantly influenced the Chamber in this regard. Thus, it might be thought that it has little general relevance to the due diligence obligation, for instance, of States in regulating transboundary hazards. Nevertheless, one can see similarities with the dicta of the ICJ in Pulp Mills in which it talked of due diligence being "an obligation which entails not only the adoption of appropriate rules and measures, but also a certain level of vigilance in their enforcement" ${ }^{142}$ Thus to the extent that the Chamber's references to reasonableness, non-arbitrariness and good faith have generic relevance, this aspect of the Advisory Opinion can be seen to have broader appeal. Moreover, although "ordinary" transboundary pollution will rarely harm special areas, such as the common heritage, the overarching notion that due diligence regulation within a State must be assessed on how reasonable it is in light of all the circumstances and consultation between itself and potentially affected States are undertaken on the basis of good faith would both seem to be non-contentious. To that extent, the Chamber has again contributed to the general jurisprudence on the due diligence requirement under customary international law.

\section{Conclusion}

It has been remarked that the Advisory Opinion has significance beyond the mere elucidation of the rights and responsibilities of sponsoring States in the Area. ${ }^{143}$ Freestone has commented that "[f]rom an international

${ }_{141}$ Ibid., paragraph 230.

142 Pulp Mills, paragraph 197.

143 This is not to negate the primary importance of the Advisory Opinion as legal guidance to the Authority: "The advisory opinion on responsibilities and obligations of States sponsoring activities in the Area rendered by the Seabed Disputes Chamber of the International Tribunal for the Law of the sea has proved to be a milestone in the life of Seabed Authority and the Law of the Sea,' the Authority's Secretary-General said this morning... 'The universal reaction to the opinion, including from academia, members of the Authority and the seabed mining industry, had been positive, in that it had provided much-needed and long-expected certainty 
environmental law point of view, this is also a historic ruling". ${ }^{144}$ I would agree and for me, the reasons for this would be five-fold. First is the affirmation and extension by the Chamber of the ICJ's understanding of due diligence, EIA and the precautionary approach. As noted above, although one must be careful not to strain too far the nuances and peculiarities of the regime put in place to govern the Area, nevertheless the Advisory Opinion raises a number of points of general significance, which will undoubtedly influence both future judicial decisions and policy discourses.

Second, as a subset of the due diligence discussion, the Chamber's comments on the importance of putting in place binding law to constrain private activity also raises a general issue of law, of particular interest as the dependency of States on private actors-both in the environmental sphere and elsewhere-is only likely to continue to grow in the years ahead. Thus, as a broad statement of principle, the Chamber's comments on the value of transparency, and by implication, legitimacy of regulations over contractual compliance is surely a sound approach in many other situations.

Third, the Chamber's discussion on the possibility of differentiation between different types of States Parties seems to me to be especially timely. Much has been said about common but differentiated responsibilities in recent years, especially within the context of the climate change regime. Debate has often focused on broad distinctions between developed and developing States and, within the context of the climate change regime in particular, how the "BRIC" (Brazil, Russia, India and China) countries are forcing changes in assumptions about these broad characterisations. The debate has been highly political and politicised. In a very different factual context, the Chamber's discussion of the issue highlights two fundamental points. First, although the existence of differentiation (insofar as it exists) within Part XI was invariably the result of State interests within the negotiations and thus reflects political compromise, equally such differentiation is capable of being understood normatively and can consequently be both legitimised and constrained through judicial interpretation. In this case, for instance, this is achieved by not permitting the level of development to be used to compromise the environmental integrity of the

in the interpretation of the obligations and responsibilities of sponsoring States under the Convention and the Agreement. It was an encouraging sign for the Authority and its members, not least because it suggested that the commercial sector was developing confidence in the legal regime for the orderly development of the resources of the Area that had been put in place over the past 13 years,' he added" (Press Release (14 July 2011), supra note 139).

${ }_{144}$ Freestone, supra note 2. 
regime through the creation of sponsoring States "of convenience". Second, and related to this, is the Chamber's comment-very much obiter, but nonetheless important in recognition of the argument that differentiation is a generic tool in need of more precise refinement-that " $[\mathrm{w}]$ hat counts in a specific situation is the level of scientific knowledge and technical capability available to a given State".

Fourth, the Advisory Opinion is notable in its treatment of the legal implications of common heritage of mankind. Although, as one would expect where the questions asked are specific and technical, there is no great opportunity for declaratory pronouncements on the status or importance of the ideal of common heritage, nevertheless the Chamber does utilise the principle at many points to inform its reasoning and to strength the obligations of sponsoring States. When discussing the rights of developing States within the Area, the idea of equity which underlies the principle is clearly noted, and similarly when highlighting the role of sponsoring States in supporting the Authority in the conduct of its affairs, it too is formulated very directly on the basis of the Authority's principal function in ensuring the "proper implementation of the principle". Moreover, the common heritage of mankind was the keystone on which the Chamber found the Authority to have the legal right to bring a claim of damages under international law: "such entitlement is implicit in ... the Authority... act[ing] "on behalf" of mankind". Common heritage may have become a rather historic and iconic idea in international politics—indeed, a little like deep seabed mining itself_-but the Chamber has done much to present it as very much an active principle of international law, as well as being a fundamental, if a discrete, element of the promotion of global sustainable development.

Finally, fifth, it is essential to recognise the Chamber's contribution to general international law and the impact this may have on international environmental law, international law on sustainable development and specifically the protection of the global commons. In this regard, the Chamber's positive assertion of the existence of a procedural right to enforce erga omnes obligations is a very good example; it is significant not only for the Area, and potentially for international environmental law but also for the long-term evolution of the international legal order. Perhaps that is the Chamber's greatest achievement; without in any way stretching its mandate or the applicable law beyond what either could bear-though admittedly sometimes acting quite creatively - the Chamber has integrated governance of the Area into the mainstream of international law of the sea, international law on sustainable development and general international law. Concurrently, the Chamber has also strengthened the LOSC, international environmental law and general 
international law through its clarification of the rights and responsibilities in the Area. For an Advisory Opinion "given as a matter of urgency" — as required by the LOSC - the judgment can rightly be viewed as an impressive contribution to international jurisprudence, and certainly should not be marginalised as being relevant only to the Area. 